\title{
The "Nullum Crimen, Nulla Poena Sine Lege" Principle and Foreseeability of the Criminal Law in the Jurisprudence of European Court of Human Rights
}

\author{
Andrei Emil Moise ${ }^{*}$ \\ Universitary Assistant, PhD, Hyperion University of Bucharest, Romania
}

DOI: $10.36348 /$ sijlcj.2020.v03i07.004

| Received: 18.07.2020 | Accepted: 25.07.2020 | Published: 28.07 .2020

*Corresponding author: Andrei Emil Moise

\section{Abstract}

Applying a similar legal provision or resorting to the principles of law, in the matter of private law, the judge has the duty to resolve any case when there is a lacunar legislation. Unlike in private law, in criminal law this is impossible, as there are two principles that prevent the court from establishing new facts as crimes and applying punishments that are not expressly provided by criminal law, namely the principle of legality of incrimination (nullum crime sine lege) and the principle of legality of punishment (nulla poena sine lege). In the present study we aimed to analyze the extent to which these principles of criminal law find their expression in the jurisprudence of the European Court of Human Rights.

Keywords: European Court of Human Rights, European Convention on Human Rights, jurisprudence, criminal law, principle of legality of incrimination (nullum crime sine lege), principle of legality of punishment (nulla poena sine lege).

Copyright @ 2020: This is an open-access article distributed under the terms of the Creative Commons Attribution license which permits unrestricted use, distribution, and reproduction in any medium for non-commercial use (NonCommercial, or CC-BY-NC) provided the original author and source are credited.

\section{INTRODUCTION}

"The purpose of law is the good of society and justice and human will acquires legal meanings only when it has a moral determination, ethics, good faith, harmonized with the general interest of society" [i].

"In any system of law based on democratic principles, any party to a legal relationship, including when this is a state authority, has an obligation to adopt a conduct that does not harm human dignity or the rights and freedoms of the citizens" [ii].

The task of protecting human rights belongs to the judiciary system and involves the control of governmental action [iii].

The principle of legality of incrimination is defined in the content of article 1 par. (1) of the current Romanian Criminal Code, which stipulates that "the criminal law provides for the deeds that constitute crimes". Therefore, regardless of the gravity of a deed, it cannot be the object of an offence, if the criminal law does not regulate it in this way (nullum crimen sine lege). Also, according to the constitutional norms, the crimes are established by organic law. According to art. 173 of the current Criminal Code, the criminal law is defined as any provision of a criminal nature contained in laws, emergency ordinances or other normative acts that at the date of their adoption acquired the force of law. Consequently, for an act to constitute a crime, it is mandatory that it be expressly provided in the criminal law.

In the process of drafting the law and, subsequently, in its application, the principle of legality of incrimination requires compliance with certain conditions. Thus, in the process of drafting the law, it is imperative that depending on the social realities, the legislator to incriminate deeds of a certain gravity, committed over time, facts that raise the issue of risk and fear that they could repeat, endangering or even harming social values that must be protected by criminal law. Another condition is that the criminal norm to be elaborated clearly and predictably, in such a way that any person to be able to understand which is the prohibited conduct prescribed in the incriminating text. In this sense, insofar as it is possible to determine all the ways of committing an act and at the same time without excessively oversizing the legal text, the material element of the crime will contain the enumeration of all prohibited actions and / or inactions. At other times, there are used generic terms, but which allow the recipients of the norm to identify the hypotheses in which the respective norm becomes incidental. If the terminology used in drafting the norm 
is susceptible of several meanings, these terms or expressions will be explained even in the law, as the case may be, in the General Part or in the Special Part of the Criminal Code. A last condition imposed in the process of drafting the law by the principle of legality of incrimination concerns the accessibility of the law, in the sense that any person must have the opportunity to find out about the existence of the criminal law, as well as about its provisions.

As we said before, also in the process of applying the criminal law, a number of conditions must be respected. Thus, the one who benefits from the competence to apply the criminal norm or the one who interprets it has the duty to observe exactly the provisions of the norm without extending the incrimination by analogy, since, otherwise, it could lead to situations of abuse and to abusive incriminations. The significance of the extension of the criminal law by analogy is that of its application in similar situations, but which are not expressly regulated. However, we do not have to understand by this an extensive interpretation, because in such situations only an extension of the scope of the meaning of the terminology used in the incrimination norm is achieved. On the other hand, it must be emphasized that the criminal law is of strictly interpretation. Interpretation is a logical and rational operation carried out during the application of the criminal law, with the aim of establishing its meaning and its limits of application in a given case. The interpretation of the criminal law can be made by the legislator, in the very content of the norm, during the elaboration process or later, finding its expression in another normative act. This is the case of the legal interpretation. Also, the interpretation can be made by the judicial bodies (judicial interpretation), but without being endowed with binding force in other cases brought before the court or for other courts. At the same time, we can also talk about a doctrinal interpretation, which is the subject of studies or specialized works of theorists.

In accordance with the existing provisions in art. 1 para. (2) of the National Criminal Code, "no person may be criminally sanctioned for an act that was not provided by the criminal law at the date when it was committed". Committing a crime involves committing an act incriminated by criminal law as an attempt or as a crime, regardless of the quality of perpetrators, instigators or accomplices of the participants.

Article 2 of the Romanian Criminal Code regulates the principle of legality of criminal sanctions, in the sense that the applicable penalties and their limits can be established only by criminal law and that no punishment can be established and applied if it was not provided by criminal law at the time of the act. The court has the obligation to comply with the criteria for individualizing the sentence, as well as the methods of execution as they were provided by law.

These principles "are the most often susceptible to abuse and, at the same time, the most representative due to their frequency and their severity of the consequences both at the international interstate level and at the level of the citizens of that state" [iv]. In what follows, we aimed to analyze the extent to which these principles of criminal law, enshrined in the text of the Criminal Code by the Romanian legislator, find their expression in the jurisprudence of the European Court of Human Rights.

\section{RESEARCH METHODS}

"The research represents an analytical, conceptual and statutory approach to a complex issue, [...] much debated at international level" [v]. "The conceptual approach refers to legal principles. These principles can be found in the views of scholars or legal doctrines" [vi] and will also find their expression in the legal norms and in the law enforcement process. "Based on the problems above, the specifics of this research, the author implements the normative legal research which is supported by the research method of the normative law" [vii] with the jurisprudence of the European Court of Human Rights. We used established research methods: documentation method, comparative method, analytical method, the logical method, examination of judicial practice or application method, in order to obtain a systematic analyze of the topic approached. All data obtained, edited, processed and selected "from literature, cases and reports [...] in order to explain, states the fact clearly in addition to avoid using irrelevant data" [viii]. We believe that "the research can contribute to the enrichment of legal doctrine, to optimize the knowledge process in this field and, obviously, to the use in practice of the ideas expressed" [ ix ]. "Personal contribution [..] is highlighted by the way in which the used concepts were analyzed, $[\ldots]$ by the personal opinions and the conclusions formulated" $[\mathrm{x}]$.

\section{DISCUSSIONS AND RESULTS}

The "nullum crimen, nulla poena sine
lege" principle

The guarantee enshrined in Article 7, which is an essential element of the rule of law, occupies a prominent place in the Convention system of protection, as is underlined by the fact that no derogation from it is permissible under Article 15 of the Convention in time of war or other public emergency threatening the life of the nation. It should be construed and applied, as follows from its object and purpose, in such a way as to provide effective safeguards against arbitrary prosecution, conviction and punishment [xi].

Article $7 \S 1$ of the Convention goes beyond prohibition of the retrospective application of criminal 
law to the detriment of the accused [xii]. It also sets forth, more generally, the principle that only the law can define a crime and prescribe a penalty (nullum crimen, nulla poena sine lege) [xiii]. While it prohibits in particular extending the scope of existing offences to acts which previously were not criminal offences, it also lays down the principle that the criminal law must not be extensively construed to an accused's detriment, for instance by analogy [xiv].

It follows that offences and the relevant penalties must be clearly defined by law. This requirement is satisfied where the individual can know from the wording of the relevant provision and, if need be, with the assistance of the courts' interpretation of it and after taking appropriate legal advice, what acts and omissions will make him criminally liable and what penalty he faces on that account $[\mathrm{xv}]$.

The Court must therefore verify that at the time when an accused person performed the act which led to his being prosecuted and convicted there was in force a legal provision which made that act punishable, and that the punishment imposed did not exceed the limits fixed by that provision [xvi].

The Court reiterates that Article 7 of the Convention embodies, in general terms, the principle that only the law can define a crime and prescribe a penalty (nullum crimen, nulla poena sine lege) and prohibits in particular the retrospective application of the criminal law where it is to an accused's disadvantage [xvii].

\section{The Concept of Penalty}

Since the concept of "penalty" in Article 7 is, like the notions of "civil right and obligations" and "criminal charge" in Article $6 \S 1$ of the Convention, autonomous in scope [xviii], to render the protection afforded by Article 7 effective, the Court must remain free to go behind appearances and assess for itself whether a particular measure amounts in substance to a "penalty" within the meaning of this provision [xix].

While the text of the Convention is the starting-point for such an assessment, the Court may have cause to base its findings on other sources, such as the travaux préparatoires. Having regard to the aim of the Convention, which is to protect rights that are practical and effective, it may also take into consideration the need to preserve a balance between the general interest and the fundamental rights of individuals and the notions currently prevailing in democratic States $[\mathrm{xx}]$.

The wording of Article $7 \S 1$, second sentence, indicates that the starting-point in any assessment of the existence of a penalty is whether the measure in question is imposed following conviction for a "criminal offence". Other factors that may be taken into account as relevant in this connection are the nature and purpose of the measure in question; its characterization under national law; the procedures involved in the making and implementation of the measure; and its severity [xxi]. The severity of the order is not in itself decisive, however, since many non-penal measures of a preventive nature may have a substantial impact on the person concerned [xxii].

To this end, both the Commission and the Court in their case-law have drawn a distinction between a measure that constitutes in substance a "penalty" and a measure that concerns the "execution" or "enforcement" of the "penalty". In consequence, where the nature and purpose of a measure relates to the remission of a sentence or a change in a regime for early release, this does not form part of the "penalty" within the meaning of Article 7 [xxiii]. However, in practice, the distinction between the two may not always be clear cut [xxiv].

In Uttley, for example, the Court found that the changes made to the rules on early release after the applicant's conviction had not been "imposed" on him but were part of the general regime applicable to prisoners and, far from being punitive, the nature and purpose of the "measure" were to permit early release, so they could not be regarded as inherently "severe". The Court accordingly found that the application to the applicant of the new regime for early release was not part of the "penalty" imposed on him [xxv].

In Kafkaris, where changes to the prison legislation had deprived prisoners serving life sentences - including the applicant - of the right to remissions of sentence, the Court considered that the changes related to the execution of the sentence as opposed to the penalty imposed on the applicant, which remained that of life imprisonment. It explained that although the changes in the prison legislation and in the conditions of release might have rendered the applicant's imprisonment harsher, these changes could not be construed as imposing a heavier "penalty" than that imposed by the trial court. It reiterated in this connection that issues relating to release policies, the manner of their implementation and the reasoning behind them fell within the power of the States Parties to the Convention to determine their own criminal policy [xxvi]. In Kafkaris it accepted that the manner in which the Prison Regulations concerning the execution of sentences had been understood and applied in respect of the life sentence the applicant was serving went beyond the mere execution of the sentence. Whereas the trial court had sentenced the applicant to imprisonment for life, the Prison Regulations explained that what that actually meant was twenty years' imprisonment, to which the prison authorities might apply any remissions of sentence [xxvii]. The Court considered that "the distinction between the scope of a life sentence and the 
manner of its execution was therefore not immediately apparent" [xxviii].

In Gurguchiani (cited above), the Court considered that the replacement of a prison sentence while it was being served - by expulsion combined with a ten-year ban on entering the country amounted to a penalty just like the one imposed when the applicant had been convicted [xxix].

In M. v. Germany (cited above), the Court considered that the extension of the applicant's preventive detention by the courts responsible for the execution of sentences, by virtue of a law enacted after the applicant had committed his offence, amounted to an additional sentence imposed on him retrospectively [xxx].

In Del Rio Prada împotriva Spaniei, par.88, the Court would emphasize that the term "imposed", used in the second sentence of Article $7 \S 1$, cannot be interpreted as excluding from the scope of that provision all measures introduced after the pronouncement of the sentence [xxxi].

In the light of the foregoing, the Court does not rule out the possibility that measures taken by the legislature, the administrative authorities or the courts after the final sentence has been imposed or while the sentence is being served may result in the redefinition or modification of the scope of the "penalty" imposed by the trial court. When that happens, the Court considers that the measures concerned should fall within the scope of the prohibition of the retroactive application of penalties enshrined in Article $7 \S 1$ in fine of the Convention. Otherwise, States would be free - by amending the law or reinterpreting the established regulations, for example - to adopt measures which retroactively redefined the scope of the penalty imposed, to the convicted person's detriment, when the latter could not have imagined such a development at the time when the offence was committed or the sentence was imposed. In such conditions Article $7 \S 1$ would be deprived of any useful effect for convicted persons, the scope of whose sentences was changed $e x$ post facto to their disadvantage. The Court points out that such changes must be distinguished from changes made to the manner of execution of the sentence, which do not fall within the scope of Article $7 \S 1$ in fine [xxxii].

In order to determine whether a measure taken during the execution of a sentence concerns only the manner of execution of the sentence or, on the contrary, affects its scope, the Court must examine in each case what the "penalty" imposed actually entailed under the domestic law in force at the material time or, in other words, what its intrinsic nature was. In doing so it must have regard to the domestic law as a whole and the way it was applied at the material time [xxxiii].

\section{Foreseeability of the criminal law}

"In order to maintain and strengthen the rule of law, the legislator must comply with the law-making procedure, not exceed its powers and take into account that any legal rule must be harmoniously integrated in the context of existing ones"[xxxiv]. When speaking of "law" Article 7 alludes to the very same concept as that to which the Convention refers elsewhere when using that term, a concept which comprises statutory law as well as case-law and implies qualitative requirements, notably those of accessibility and foreseeability [xxxv]. These qualitative requirements must be satisfied as regards both the definition of an offence and the penalty the offence carries [xxxvi].

It is a logical consequence of the principle that laws must be of general application that the wording of statutes is not always precise. One of the standard techniques of regulation by rules is to use general categorizations as opposed to exhaustive lists. That means that many laws are inevitably couched in terms which, to a greater or lesser extent are vague, and their interpretation and application are questions of practice [xxxvii]. Consequently, in any system of law, however clearly drafted a legal provision may be, including a criminal law provision, there is an inevitable element of judicial interpretation. There will always be a need for elucidation of doubtful points and for adaptation to changing circumstances. Again, whilst certainty is highly desirable, it may bring in its train excessive rigidity and the law must be able to keep pace with changing circumstances [xxxviii].

The role of adjudication vested in the courts is precisely to dissipate such interpretational doubts as remain [xxxix]. Moreover, it is a firmly established part of the legal tradition of the States party to the Convention that case-law, as one of the sources of the law, necessarily contributes to the gradual development of the criminal law [xl]. Article 7 of the Convention cannot be read as outlawing the gradual clarification of the rules of criminal liability through judicial interpretation from case to case, provided that the resultant development is consistent with the essence of the offence and could reasonably be foreseen [xli]. The lack of an accessible and reasonably foreseeable judicial interpretation can even lead to a finding of a violation of the accused's Article 7 rights [xlii]. Were that not the case, the object and the purpose of this provision - namely that no one should be subjected to arbitrary prosecution, conviction or punishment would be defeated [xliii].

Foreseeability depends to a considerable degree on the content of the law concerned, the field it is designed to cover and the number and status of those to whom it is addressed. A law may still satisfy the requirement of "foreseeability" where the person concerned has to take appropriate legal advice to assess, 
to a degree that is reasonable in the circumstances, the consequences which a given action may entail [xliv].

In 1978 the European Commission of Human Rights expressed the opinion that, unlike Article $15 \S$ 1 in fine of the United Nations Covenant on Civil and Political Rights, Article 7 of the Convention did not guarantee the right to a more lenient penalty provided for in a law subsequent to the offence [ xlv ]. It accordingly declared manifestly ill-founded the complaint of an applicant who alleged that, after their commission, some of the offences he had been charged with had been decriminalized. That ruling has been repeated by the Court, which has reiterated that Article 7 does not afford the right of an offender to application of a more favorable criminal law [xlvi].

While the Court is not formally bound to follow any of its previous judgments, it is in the interests of legal certainty, foreseeability and equality before the law that it should not depart, without cogent reason, from precedents laid down in previous cases [xlvii]. Since the Convention is first and foremost a system for the protection of human rights, the Court must however have regard to the changing conditions in the respondent State and in the Contracting States in general and respond, for example, to any emerging consensus as to the standards to be achieved [xlviii]. It is of crucial importance that the Convention is interpreted and applied in a manner which renders its rights practical and effective, not theoretical and illusory. A failure by the Court to maintain a dynamic and evolutive approach would risk rendering it a bar to reform or improvement [xlix].

The Court considers that a long time has elapsed since the Commission gave the abovementioned $X v$. Germany decision and that during that time there have been important developments internationally. In particular, apart from the entry into force of the American Convention on Human Rights, Article 9 of which guarantees the retrospective effect of a law providing for a more lenient penalty enacted after the commission of the relevant offence, mention should be made of the proclamation of the European Union's Charter of Fundamental Rights. The wording of Article $49 \S 1$ of the Charter differs - and this can only be deliberate [1]-from that of Article 7 of the Convention in that it states: "If, subsequent to the commission of a criminal offence, the law provides for a lighter penalty, that penalty shall be applicable". In the case of Berlusconi and Others, the Court of Justice of the European Communities, whose ruling was endorsed by the French Court of Cassation, held that this principle formed part of the constitutional traditions common to the member States. Lastly, the applicability of the more lenient criminal law was set forth in the statute of the International Criminal Court and affirmed in the case-law of the ICTY [li].
The Court therefore concludes that since the $X v$. Germany decision a consensus has gradually emerged in Europe and internationally around the view that application of a criminal law providing for a more lenient penalty, even one enacted after the commission of the offence, has become a fundamental principle of criminal law. It is also significant that the legislation of the respondent State had recognized that principle since 1930 [lii].

Admittedly, Article 7 of the Convention does not expressly mention an obligation for Contracting States to grant an accused the benefit of a change in the law subsequent to the commission of the offence. It was precisely on the basis of that argument relating to the wording of the Convention that the Commission rejected the applicant's complaint in the case of $X v$. Germany. However, taking into account the developments mentioned above, the Court cannot regard that argument as decisive. Moreover, it observes that in prohibiting the imposition of "a heavier penalty ... than the one that was applicable at the time the criminal offence was committed", paragraph 1 in fine of Article 7 does not exclude granting the accused the benefit of a more lenient sentence, prescribed by legislation subsequent to the offence [liii].

In the Court's opinion, it is consistent with the principle of the rule of law, of which Article 7 forms an essential part, to expect a trial court to apply to each punishable act the penalty which the legislator considers proportionate. Inflicting a heavier penalty for the sole reason that it was prescribed at the time of the commission of the offence would mean applying to the defendant's detriment the rules governing the succession of criminal laws in time. In addition, it would amount to disregarding any legislative change favorable to the accused which might have come in before the conviction and continuing to impose penalties which the State - and the community it represents - now consider excessive. The Court notes that the obligation to apply, from among several criminal laws, the one whose provisions are the most favorable to the accused is a clarification of the rules on the succession of criminal laws, which is in accord with another essential element of Article 7, namely the foreseeability of penalties [liv].

In the light of the foregoing considerations, the Court takes the view that it is necessary to depart from the case-law established by the Commission in the case of $X v$. Germany and affirm that Article $7 \S 1$ of the Convention guarantees not only the principle of non-retrospectiveness of more stringent criminal laws but also, and implicitly, the principle of retrospectiveness of the more lenient criminal law. That principle is embodied in the rule that where there are differences between the criminal law in force at the time of the commission of the offence and subsequent criminal laws enacted before a final judgment is 
rendered, the courts must apply the law whose provisions are most favorable to the defendant [lv].

\section{CONCLUSIONS}

From what is shown in this study, it results that in the vision of the European Court of Human Rights, the prohibition of analogy can be absolute, but also relative, as its effects are against or in favor of the defendant. Therefore, when the analogy is to the detriment of the defendant, its prohibition can only be absolute. The analogy proves a relative character when it is favorable to the defendant, but for the examined hypothesis it must not be possible the incidence of the other incrimination norms as an effect of its interpretation. Also, if there are omissions in the criminalization rule, these omissions must not be the will of the legislator, in the sense of limiting, for example, the commission of the act only in certain ways. At the same time, if an exceptional law, which is favorable to the defendant, such as that of pardon or amnesty, it can never be applied by analogy, being of strict interpretation.

The qualitative requirements of accessibility and foreseeability concerning the law must be satisfied as regards both the definition of an offence and the penalty the offence in question carries. It is unacceptable that a person to not be able to understand from the wording of the relevant provision what acts and omissions will make him criminally liable and what penalty will be imposed for the act committed and/or omission.

\section{REFERENCES}

1. Nour, A. (2018). Theoretical and Practical Consideratons Regarding the Power Abuse. Proceeding of the International Conference of Law, European Studies and International Relations. Bucharest: Hamangiu S.R.L. Publishing House. VI, 627. Available on https://www.ceeol.com/search/articledetail $?$ id $=826452$

2. Nour, A. (2020). Chemical Castration of the Sexual Offender versus Human Fundamental Rights and Freedoms. Scholars International Journal of Law, Crime and Justice. Dubai: Scholars Middle East Publisher. 3(5), 144. DOI: 10.36348/sijlcj.2020.v03i05.002. Available on https://saudijournals.com/sijlcj

3. Cappelletti, M. (1971). Judicial Review in the Contemporary World. Bobbs-Merril Publishing House. In Schutze, R. (2012). Dreptul constituțional al Uniunii Europene. Bucharest: Editura Universitară.

4. [ $\left.{ }^{\mathrm{iv}}\right]$ Nour, A. (2019). De la litera legii la destabilizarea ordinii de drept. Bucharest: C.H. Beck Publishing House. 78.
5. Nour, A. (2020). Euthanasia - A Right of the Human Being or a Crime against Humanity? Scholars International Journal of Law, Crime and Justice. Dubai: Scholars Middle East Publisher. 3(5), 141. DOI: 10.36348/sijlcj.2020.v03i05.001. Available on https://saudijournals.com/sijlcj

6. Susetyani, R., Muryanto, Y. T., Pujiono (2020). The Implementation of the Decision of Kpu In Relation to the Objection of Business Actors Due to Tender Conspiracy Case. Scholars International Journal of Law, Crime and Justice. Dubai: Scholars Middle East Publisher. 3(2), 52. DOI: 10.36348/sijlcj.2020.v03i02.001. Available on https://saudijournals.com/sijlcj.

7. [Mediheryanto, Rumengan, J., Fadlan (2020). Analysis of Juridical Legal Protection of Women Reproductive Health in Family Planning: A Research Study in Batam City. Scholars International Journal of Law, Crime and Justice. Dubai: Scholars Middle East Publisher. 3(7), 209. DOI: 10.36348/sijlcj.2020.v03i07.001. Available on https://saudijournals.com/sijlcj.

8. Sakharina, I.K., Daud, A.A. (2020). Abolition of Child Marriage Practices in Indonesia According to the United Nations Convention on the Rights of the Child. Scholars International Journal of Law, Crime and Justice. Dubai: Scholars Middle East Publisher. 3(6), 203. DOI: 10.36348/sijlcj.2020.v03i06.009. Available on https://saudijournals.com/sijlcj.

9. Nour, A. (2018). Corruption - Aggravated Cause of Violations of the Rule of Law. Current Issues in Business Law Contributions to the 8th International Conference Perspectives of Business Law in the Third Millennium. Bucharest: ADJURIS - International Academic Publisher. 158. Available on http://www.adjuris.ro/reviste/ciibl/Current\%20Issu es\%20in\%20Business\%20Law.pdf

10. Nour, A. (2019). The Crime of Traffic of Influence in the New Incrimination Formula. Perspectives of Law and Public Administration. Bucharest: ADJURIS - International Academic Publisher. 8(2), 358. Available on http://www.adjuris.ro/revista/articole/an8nr2/25.\% 20Andrada $\% 20$ Nour $\% 20$ $\% 20$ Lucrarea\%20nr.\%202.pdf

11. See among the others, the judgment Scoppola v. Italy (no. 2) of 17th of September 2009 (for application no. 10249/03), § 92; S.W. v. the United Kingdom, 22 November 1995, § 34, Series A no. 335-B; C.R. v. the United Kingdom, 22 November 1995, § 32, Series A no. 335-C; Kafkaris v. Cyprus [GC], no 21906/04,12 February 2008, § 137; Del Rio Prada v. Spain [GC] no. 42750/09, 21 October 2013, § 77.

12. See among the others Scoppola $\S 93$; Del Rio Prada, $\S 78$, both cited above; Coëme and Others 
v. Belgium, nos. 32492/96, 32547/96, 32548/96, $33209 / 96$ and 33210/96, § 145, ECHR 2000-VII.

13. See among the others Scoppola, § 93; S.W., § 35; C.R., $§ 33$ all cited above; Kokkinakis v. Greece, 25 May 1993, $\S 52$, Series A no. 260-A. Concerning the retrospective application of a penalty, see Welch v. the United Kingdom, 9 February 1995, § 36, Series A no. 307-A; Jamil v. France, 8 June 1995, $\S 35$, Series A no. 317-B; Ecer and Zeyrek v. Turkey, nos. 29295/95 and 29363/95, § 36, ECHR 2001-II and Mihai Toma v. Romania, no. 1051/06, §§ 2631, 24 January 2012.

14. See among others, Scoppola, § 93; Del Rio Prada, $\S 78$; Coëme and Others, § 145; S.W., § 35; C.R., $\S 33$, all cited above. For an example of the application of a penalty by analogy, see Başkaya and Okçuoğlu v. Turkey [GC], nos. 23536/94 and 24408/94, $§ \S 42-43$, ECHR 1999-IV.

15. See among the other authorities, Kokkinakis, $\S$ 52; Kafkaris, § 140; S.W., § 35; C.R., § 33; Del Rio Prada, § 79; Scoppola § 94, all cited above. See also, Achour v. France [GC], no. 67335/01, § 41, ECHR 2006-IV; Sud Fondi Srl and Others v. Italy, no. 75909/01, § 107, 20 January 2009; Cantoni v. France, 15 November 1996, § 29, Reports of Judgments and Decisions 1996-V.

16. See Coëme and Others, $\S 145$; Achour, $\S ~ 43$; Del Rio Prada, § 80; Scoppola, § 95, all cited above. See also Murphy v. the United Kingdom, application no. 4681/70, Commission decision of 3 and 4 October 1972, Collection 43, p. 1.

17. See Kokkinakis, $\S 52$; Coëme and Others, $\S 145$; Achour, §41, all cited above. See also, Dragotoniu şi Militaru-Pidhorni v. Romania, nos. 77193/01 and 77196/01, § 33, 24 May 2007.

18. See in particular, regarding "civil rights”, X v. France, 31 March 1992, § 28, Series A no. 234-C, and, on the subject of "criminal charges", Demicoli v. Malta, 27 August 1991, $\S 31$, Series A no. 210. See also, Scoppola, § 96; Kafkaris, $\S 142$, both cited above.

19. See Welch, § 27; Jamil, § 30; Del Rio Prada, § 81; Scoppola, § 96; Kafkaris, § 142; Coëme and Others, $\S 145$, all cited above.

20. See, among other authorities, the Airey v. Ireland judgment of 9 October 1979, Series A no. 32, pp. $14-15, \S 26$; the Guzzardi v. Italy judgment of 6 November 1980, Series A no. 39, pp. 34-35, § 95; Coëme and Others, cited above, $\S 145$.

21. See Welch, § 28; Jamil, § 31; Kafkaris, § 142; Del Rio Prada, § 82; Scoppola, § 97, all cited above.

22. See Welch, $\S 32$; Del Rio Prada, $\S 82$; Kafkaris, $\S$ 142 , all cited above and Van der Velden v. the Netherlands (dec.), no. 29514/05, ECHR 2006-XV.

23. See, inter alia, Hogben v. the United Kingdom, no. 11653/85, Commission decision of 3 March 1986,
Decisions and Reports 46, p. 231; Grava v. Italy no. 43522/98, §51, 10 July 2003; Uttley v. the United Kingdom (dec.) no. 36946/03, 29 November 2005, § 51; Gurguchiani v. Spain, no. $16012 / 06$, § 31, 15 December 2009; M. v. Germany, no. 19359/04, § 121, ECHR 2009; Hosein v. the United Kingdom, no. 26293/95, Commission decision of 28 February 1996, unreported; L.-G.R. v. Sweden, no. 27032/95, Commission decision of 15 January 1997; Monne v. France (dec.), no. 39420/06, 1 April 2008; Giza v. Poland (dec.), no. 1997/11, § 31, 23 October 2012. See also, Scoppola, § 98; Del Rio Prada, §§ 83, 85; Kafkaris, § 142, all cited above.

24. See Del Rio Prada, $\S 85$; Kafkaris, $\S$ 142; Gurguchiani, § 31 and M. v. Germany, § 121, all cited above.

25. See Del Rio Prada, $\S 83$, cited above.

26. See Achour, $\S 44$; Del Rio Prada, $\S 84$ and Kafkaris, $\S 151$, all cited above.

27. See Del Rio Prada, $\S 85$, cited above.

28. See Del Rio Prada, $\S 85$; Kafkaris, $\S 148$, both cited above

29. See Del Rio Prada, $\S 86$, cited above.

30. See Del Rio Prada, $\$ 87$, cited above.

31. See Del Rio Prada, $\S 88$ and Scoppola, § 104, both cited above. See also, Hirsi Jamaa and Others v. Italy [GC], no. 27765/09, § 175, ECHR 2012.

32. See Del Rio Prada, $\S 89$, cited above.

33. See Del Rio Prada, § 90; Kafkaris, § 145, both cited above.

34. Nour, A. (2018). Legal Interpretation Connection between the Letter and Spirit of the Law. Proceeding of the International Conference of Law, European Studies and International Relations. Bucharest: Hamangiu S.R.L. Publishing House. VI, 614. Available on https://www.ceeol.com/search/articledetail id $=826450$

35. See S.W., § 35; C.R., § 33; Cantoni, § 29; Coëme and Others, $\S \quad 145$; Kafkaris, $\S \quad 141$; Kokkinakis, §§ 40-41; Scoppola, § 99; Del Rio Prada, § 91, all cited above, and E.K. v. Turkey, no. 28496/95, § 51, 7 February 2002.

36. See Del Rio Prada, § 91, cited above.

37. See Cantoni, § 31; Kokkinakis, § 40; Scoppola, § 100; Kafkaris, § 141; Del Rio Prada $§ 92$, all cited above.

38. See Scoppola, § 100; Kafkaris, § 141; Del Rio Prada, § 92, all cited above.

39. See Kafkaris, $§ 141$; Del Rio Prada, $\S 93$; Scoppola, § 101, all cited above.

40. See Del Rio Prada, § 93; Scoppola, § 101, both cited above and Kruslin v. France, 24 April 1990, $\S 29$, Series A no. 176-A.

41. See Streletz, Kessler and Krenz v. Germany [GC], nos. 34044/96, 35532/97 and 44801/98, § 50, ECHR 2001-II; K.-H.W. v. Germany [GC], no. 37201/97, § 85, 22 March 2001; Korbely v. 
Hungary [GC], no. 9174/02, § 71, ECHR 2008; Kononov v. Latvia [GC], no. 36376/04, § 185, ECHR 2010. See also, S.W., § 36; C.R., § 34; Del Rio Prada, § 93; Scoppola, § 101, all cited above.

42. See Del Rio Prada, $\S 93$, cited above. See, concerning the constituent elements of the offence, Pessino v. France, no. 40403/02, §§ 3536, 10 October 2006, and Dragotoniu and Militaru-Pidhorni v. Romania, nos. 77193/01 and 77196/01, §§ 43-44, 24 May 2007. As regards the penalty, see Alimuçaj v. Albania, no. 20134/05, $\S$ 154-62, 7 February 2012.

43. See Del Rio Prada, $\S 93$, cited above.

44. See Achour, § 54; Scoppola, § 102; Kafkaris, § 141, all cited above.

45. See Scoppola, $\S 103$, cited above, and $X$ v. Germany, no. 7900/77, Commission decision of 6 March 1978, Decisions and Reports (DR) 13, pp. 70-72.

46. See Scoppola, $\S 103$, cited above and Le Petit v. the United Kingdom, no. 35574/97, 5 December 2000; Zaprianov v. Bulgaria (dec.), no. 41171/98, 6 March 2003.

47. See Scoppola, § 104, cited above and Chapman v. the United Kingdom [GC], no. 27238/95, § 70, ECHR 2001-I.

48. See Scoppola, § 104, cited above, and Cossey v. the United Kingdom, 27 September 1990, § 35, Series A no. 184; Stafford v. the United Kingdom [GC], no. 46295/99, §§ 67-68, ECHR2002-IV.

49. See Stafford, § 68; Scoppola, $\S ~ 104 ;$ Del Rio Prada, § 88; Hirsi Jamaa and Others, § 175, all cited above, and Christine Goodwin v. the United Kingdom [GC], no. 28957/95, §74, ECHR 2002VI.

50. See, mutatis mutandis, Christine Goodwin, cited above, $\S 100$ in fine.

51. See Scoppola v. Italy (nr.2), § 105 .

52. See Scoppola v. Italy (nr.2), § 106.

53. See Scoppola v. Italy (nr.2), § 107.

54. See Scoppola v. Italy (nr.2), § 108.

55. See Scoppola v. Italy (nr.2), § 109. 